\title{
Development of enucleated mouse oocytes reconstituted with embryonic nuclei
}

\author{
T. Kono, O. Y. Kwon and T. Nakahara \\ NODAI Research Institute, Tokyo University of Agriculture, Setagaya-ku, \\ Tokyo 156, Japan
}

\begin{abstract}
Summary. The chromosomes of mouse oocytes at telophase of the first meiotic division were removed using micromanipulation and differential interference microscopy. The enucleated oocytes were used as recipients for nuclear transplantation, after culture for $4-6 \mathrm{~h}$. The newly synthesized proteins of the enucleated oocytes showed the same pattern as those of secondary oocytes matured in vivo. When the enucleated oocytes received a nucleus from late 2- and 8-cell embryos, or a cell from the inner cell mass (ICM) of blastocysts, 23,4 and 10\%, respectively, of reconstituted embryos developed to blastocysts. After transfer to recipient females, live young were produced from the reconstituted eggs that received a nucleus from late 2-cell embryos.
\end{abstract}

Keywords: nuclear transplantation; mouse; oocytes; enucleation; live young

\section{Introduction}

Nuclear transplantation studies with mice and rats have shown that enucleated zygotes which received nuclei from either late 2-cell or more advanced embryos exhibited limited preimplantation development (McGrath \& Solter, 1984; Robl et al., 1986; Tsunoda et al., 1987; Kono \& Tsunoda, 1988). Transplantation of single nuclei from a 4-cell mouse embryo into one of the enucleated blastomeres of a 2-cell embryo resulted in the successful production of identical triplet mice (Kono et al., 1991), but it is difficult to produce live young by such nuclear transplantation between highly asynchronous embryos. In amphibians, fertile adults have been produced from blastula nuclei (Rana: Briggs \& King, 1952) and from intestine nuclei (Xenopus: Gurdon \& Uehlinger, 1966) transferred into enucleated oocytes. These studies show that nuclei transferred into enucleated oocytes could be reprogrammed to support normal development (review in Briggs, 1979; DiBerardino, 1980). Based on this concept, offspring were successfully produced in sheep (Willadsen, 1986) and cattle (Prather $e t$ al., 1987) from enucleated secondary oocytes which received nuclei from 8-16-cell embryos. At that time, however, the complete removal of metaphase II chromosomes from ovulated oocytes was unreliable as the chromosomes at this stage could not be readily recognized using phase-contrast or interference microscopy. The successful enucleation of the oocyte was associated with a significant reduction in ooplasmic volume.

Chromosomes at metaphase of the second meiotic division can be easily recognized when they are stained with Hoechst dye and viewed by fluorescence microscopy (Ebert et al., 1985). Using this method, Tsunoda et al. (1988) reported a reliable procedure for the enucleation of secondary mouse oocytes in which the chromosomes, visible after Hoechst staining, were removed by standard micromanipulation techniques. However, ultraviolet irradiation is reported to damage the developmental ability of preimplantation mouse embryos, especially in combination with Hoechst staining (Eibs \& Spielman, 1977; Ebert et al., 1985).

In this paper, we report the removal of chromosomes at telophase of the first meiotic division without fluorescence staining, and the developmental potential of the reconstituted embryos. Using 
the present method, we succeeded in producing live young after transfer to recipients of enucleated oocytes which had received a nucleus from late 2-cell embryos.

\section{Materials and Methods}

Collection of oocytes and embryos. $\mathrm{F}_{1}$ hybrid $(\mathrm{C} 57 \mathrm{BL} / 6 \mathrm{~J} \times \mathrm{CBA})$ female mice were used as oocyte donors and female mice of strain CD-1 were used to produce 2- and 8-cell embryos. They were superovulated by injections of 5 iu pregnant mares' serum gonadotrophin (PMSG; Peamex, Sankyo Ltd, Tokyo, Japan) and 5 iu human chorionic gonadotrophin (hCG; Puberogen, Sankyo Ltd) given $48 \mathrm{~h}$ apart. Oocytes at telophase of the first meiotic division and freshly ovulated oocytes at metaphase II were released from ovarian follicles and oviducts at 9-11 and $12 \mathrm{~h}$, respectively. Cumulus cells were removed by treatment with 300 iu hyaluronidase/ml in M2 medium (Quinn, 1982) and washed several times. After the injection of hCG, CD-1 females were paired with males of the same strain, and late 2and 8-cell embryos were collected by flushing the oviducts with M2 medium $44-46$ and $64-66 \mathrm{~h}$ after hCG injection, respectively. To obtain blastocysts for the preparation of inner cell mass (ICM) cells, spontaneously ovulating CD-1 females were mated with males of the same strain and the uterus was flushed at 3.5 days post coitum.

Hoechst staining. To examine the stage of meiotic maturation and position of chromosomes, oocytes were stained with Hoechst 33342 (Calbiochem-Behring Corp., San Diego, USA) in M2 medium ( $10 \mu \mathrm{g} / \mathrm{ml}$ ) for $10 \mathrm{~min}$ at room temperature and washed with M2 medium several times. Oocytes were placed in a small drop of M2 medium on a micromanipulation glass slide covered with paraffin oil. The oocytes were secured by a holding pipette and observed using fluorescent microscopy.

Enucleation of oocytes. Oocytes were collected from ovarian follicles $10 \mathrm{~h}$ after hCG injection, and the telophase chromosomes were removed. The zonae pellucidae of the oocytes were slit with a glass needle along $10-20 \%$ of their circumference and placed in a small drop of $\mathrm{M} 2$ medium containing cytochalasin $\mathrm{B}(5 \mu \mathrm{g} / \mathrm{ml})$ on a micromanipulation glass slide covered with paraffin oil. The oocytes were secured by a holding pipette opposite the slit in the zona. An enucleation pipette of $20 \mu \mathrm{m}$ in diameter, with an unsharpened bevelled tip, was used to remove the meiotic chromosomes and associated spindle apparatus from the oocyte. The enucleation pipette was inserted into the perivitelline space through the slit and the tip was orientated to cover the first polar body. Following aspiration of the first polar body, telophase chromosomes with spindles were aspirated into the enucleation pipette with a small amount of cytoplasm (Fig. 1). If the chromosomes were not able to be identified in an enucleation pipette at the time of sucking, the oocytes were eliminated. In order to confirm that the enucleation method was reliable, the enucleated oocytes were stained with Hoechst 33342 and observed using fluorescent microscopy. None of the enucleated oocytes examined (50) had chromosomes. All procedures were performed using Nikon Diaphot microscopy and Narishige micromanipulators.

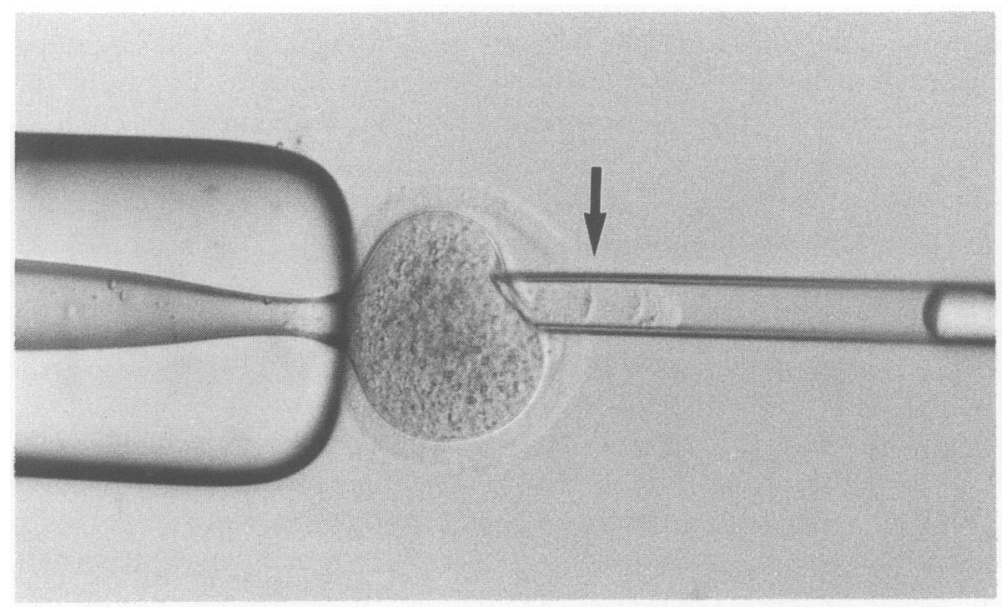

Fig. 1. Removal of anaphase chromosomes at the first meiotic division from a mouse oocyte by micromanipulation. Arrow shows the anaphase chromosomes with spindle when aspirated into an enucleation pipette $(\times 400)$. 
Nuclear transplantation. Following enucleation, the oocytes were cultured in M16 medium for $4-6 \mathrm{~h}$ and were then subjected to nuclear transplantation. This gives a high activation rate in the reconstituted eggs (T. Kono, unpublished data). Nuclear transplantation was carried out as described by McGrath \& Solter (1983) and Tsunoda et al. (1986). An ICM cell or a karyoplast from late 2- and 8-cell donor embryos was introduced with inactivated Sendai virus (HVJ) 2700 haemagglutinating activity units $/ \mathrm{ml}$ ) into the perivitelline space of the enucleated and preincubated oocytes. The manipulated oocytes were cultured in M16 medium (Whittingham, 1971) in an atmosphere of $5 \% \mathrm{CO}_{2}$, $5 \% \mathrm{O}_{2}$ and $90 \% \mathrm{~N}_{2}$ at $37^{\circ} \mathrm{C}$. Most oocytes fused with the nuclear karyoplasts within $15 \mathrm{~min}$. At 15-30 min after fusion, the reconstituted eggs were activated with $7 \%$ ethanol for $7 \mathrm{~min}$ at room temperature (Cuthbertson, 1983).

Preparation of ICM cells. Single cells from the ICM were obtained from blastocysts by immunosurgery. Following removal of the zonae pellucidae with acid Tyrode solution, the blastocysts were incubated in M16 medium containing a rabbit anti-serum against mouse spleen $(1: 100 \mathrm{v} / \mathrm{v})$ for $30 \mathrm{~min}$ in an atmosphere of $5 \% \mathrm{CO}_{2}, 5 \% \mathrm{O}_{2}$ and $90 \% \mathrm{~N}_{2}$ at $37^{\circ} \mathrm{C}$, and then treated with guinea-pig complement $(1: 20 \mathrm{v} / \mathrm{v}$ in $\mathrm{M} 2)$ for $30 \mathrm{~min}$ at $37^{\circ} \mathrm{C}$. The isolated ICM was incubated in $\mathrm{M} 2$ medium free from $\mathrm{Ca}^{2+}$ and $\mathrm{Mg}^{2+}$ and supplemented with $0 \cdot 2 \%$ EDTA and $0.025 \%$ trypsin at $37^{\circ} \mathrm{C}$ for $15 \mathrm{~min}$ and pipetted into single cells.

Culture and transfer. After nuclear transplantation and activation, the reconstituted eggs were cultured in individual drops of M16 medium containing $100 \mu \mathrm{M}$ EDTA, covered with paraffin oil, in an atmosphere of $5 \% \mathrm{CO}_{2}, 5 \% \mathrm{O}_{2}$ and $90 \% \mathrm{~N}_{2}$ at $37^{\circ} \mathrm{C}$. Blastocysts developed from reconstituted eggs were transferred to the right uterine horn of Day3 (2.5 days post coitum) pseudopregnant recipients (CD-1 strain). Control blastocysts derived from CD-1 females mated with $F_{1}$ males were transferred to the left uterine horn of the same recipients.

Sodium dodecyl sulphate polyacrylamide gel electrophoresis. Enucleated and nonenucleated oocytes were incubated for $2 \mathrm{~h}$ in M 16 medium containing $200 \mu \mathrm{Ci}\left[{ }^{35} \mathrm{~S}\right]$-methionine $(1000 \mathrm{Ci} / \mathrm{mmol}$, NEG). Five to 10 oocytes were washed 5 times with protein-free M2 medium and placed in $10 \mu$ double-strength SDS sample buffer (Laemmli, 1970) and stored at $-80^{\circ} \mathrm{C}$. Proteins were separated on 7.5-15\% SDS polyacrylamide gradient gels as described by Flach $e t$ al. (1982). After electrophoresis, gels were processed as described by Bonner \& Laskey (1974) and exposed to Fuji RX $\mathrm{X}$-ray film for fluorography at $-80^{\circ} \mathrm{C}$.

\section{Results}

\section{First meiotic division and removal of the chromosomes}

Extrusion of the first polar body was observed in $>80 \%$ of oocytes collected from ovarian follicles at $10 \mathrm{~h}$ after hCG injection and $90 \%$ were recognized to be at telophase of the first meiotic division (Table 1). The proportion of oocytes at this stage of the first meiotic division rapidly decreased with time after hCG injection. The majority of oocytes collected from oviducts at $12 \mathrm{~h}$ after hCG had progressed to metaphase II and only $10 \%$ of the oocytes had their chromosomes enclosed by the region destined to form the first polar body. In contrast, most oocytes collected at $9 \mathrm{~h}$ after hCG had not emitted the first polar body.

Table 1. Distribution of chromosome position in mouse oocytes

\begin{tabular}{|c|c|c|c|c|c|c|}
\hline \multirow{2}{*}{$\begin{array}{l}\text { Time after injection } \\
\text { with human chorionic } \\
\text { gonadotrophin } \\
\text { (h) }\end{array}$} & \multirow{2}{*}{$\begin{array}{c}\text { No. of } \\
\text { oocytes } \\
\text { examined }\end{array}$} & \multicolumn{5}{|c|}{$\begin{array}{c}\% \text { of oocytes with chromosomes } \\
\text { located in position* }\end{array}$} \\
\hline & & 1 & 2 & 3 & 4 & 5 \\
\hline 9 & 82 & 100 & 0 & 0 & 0 & 0 \\
\hline 10 & 102 & 90 & 7 & 3 & 0 & 0 \\
\hline 11 & 101 & 62 & 23 & 9 & 6 & 0 \\
\hline 12 & 100 & 10 & 41 & 20 & 17 & 12 \\
\hline
\end{tabular}

*See Fig. 2.

These results demonstrated that the oocyte at $10 \mathrm{~h}$ after hCG injection was accessible to enucleation. The chromosomes with spindle were completely removed from $95 \%$ of oocytes: those in which chromosomes sucked into an enucleation pipette were readily identified using differential interference microscopy without the use of Hoechst staining (Fig. 1). 


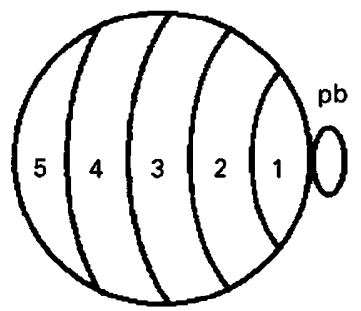

Fig. 2. Diagram of mouse oocyte showing 5 positions in relation to the first polar body (pb).

\section{Development of the reconstituted oocytes}

More than $90 \%$ of oocytes fused with a nuclear karyoplast from donor late 2- and 8-cell embryos or with an ICM cell, within $15 \mathrm{~min}$ of micromanipulation (Table 2). The proportion of oocytes that activated following exposure to ethanol and exhibited pronuclear-like swelling of the transferred nucleus was $72-90 \%$. In most of the activated oocytes, emission of a polar body that contained chromosomes was observed within $2 \mathrm{~h}$ of the activation treatment, whether the nucleus was derived from a late 2-cell embryo, an 8-cell embryo or an ICM cell.

Table 2. Development of enucleated mouse oocytes reconstituted with embryonic nuclei in vitro

\begin{tabular}{lccccc}
\hline \multirow{2}{*}{$\begin{array}{l}\text { Nuclei of } \\
\text { donor embryo }\end{array}$} & $\begin{array}{c}\text { No. of oocytes } \\
\text { fused/no. of } \\
\text { oocytes manipulated }\end{array}$ & $\begin{array}{c}\text { No. of eggs } \\
\text { activated }\end{array}$ & 2-cell & 8-cell & Blastocyst \\
\cline { 4 - 6 } & $102 / 110(93)$ & $88(86)$ & $79(90)$ & $30(29)$ & $20(23)$ \\
\hline 2-cell & $29 / 32(91)$ & $26(90)$ & $15(58)$ & $2(8)$ & $1(4)$ \\
8-cell & $148 / 160(93)$ & $107(72)$ & $96(90)$ & $16(15)$ & $11(10)$ \\
\hline Inner cell mass & & &
\end{tabular}

Values in parentheses are percentages.

After transfer to recipient females of 25 blastocysts derived from oocytes reconstituted with a nucleus from late 2-cell embryos, 3 live fetuses ( $8 \%$ ) were recovered by Caesarean section on Day 19 of gestation (Table 3). However, development to term was not observed in mice that received blastocysts derived from oocytes reconstituted with 8-cell nuclei or ICM cells.

Table 3. Development of mouse blastocysts derived by transfer of nuclei to enucleated oocytes and after transfer to recipients

\begin{tabular}{lccc}
\hline $\begin{array}{l}\text { Nuclei of } \\
\text { donor embryos }\end{array}$ & $\begin{array}{c}\text { No. pregnant } \\
\text { /no. of } \\
\text { recipients }\end{array}$ & $\begin{array}{c}\text { No. of } \\
\text { embryos } \\
\text { transferred }\end{array}$ & $\begin{array}{c}\text { No. of } \\
\text { live young } \\
(\%)\end{array}$ \\
\hline 2-cell & $9 / 10$ & 20 & $3(15)$ \\
8-cell & $1 / 1$ & 1 & 0 \\
Inner cell mass & $6 / 6$ & 11 & 0 \\
\hline
\end{tabular}

Control blastocysts were transferred to the same recipients to ensure the pregnancy.

\section{Protein profiles}

The major proteins synthesized by freshly obtained oocytes and enucleated oocytes showed similar patterns (Fig. 3) and did not change significantly during maturation in vivo or in vitro, 


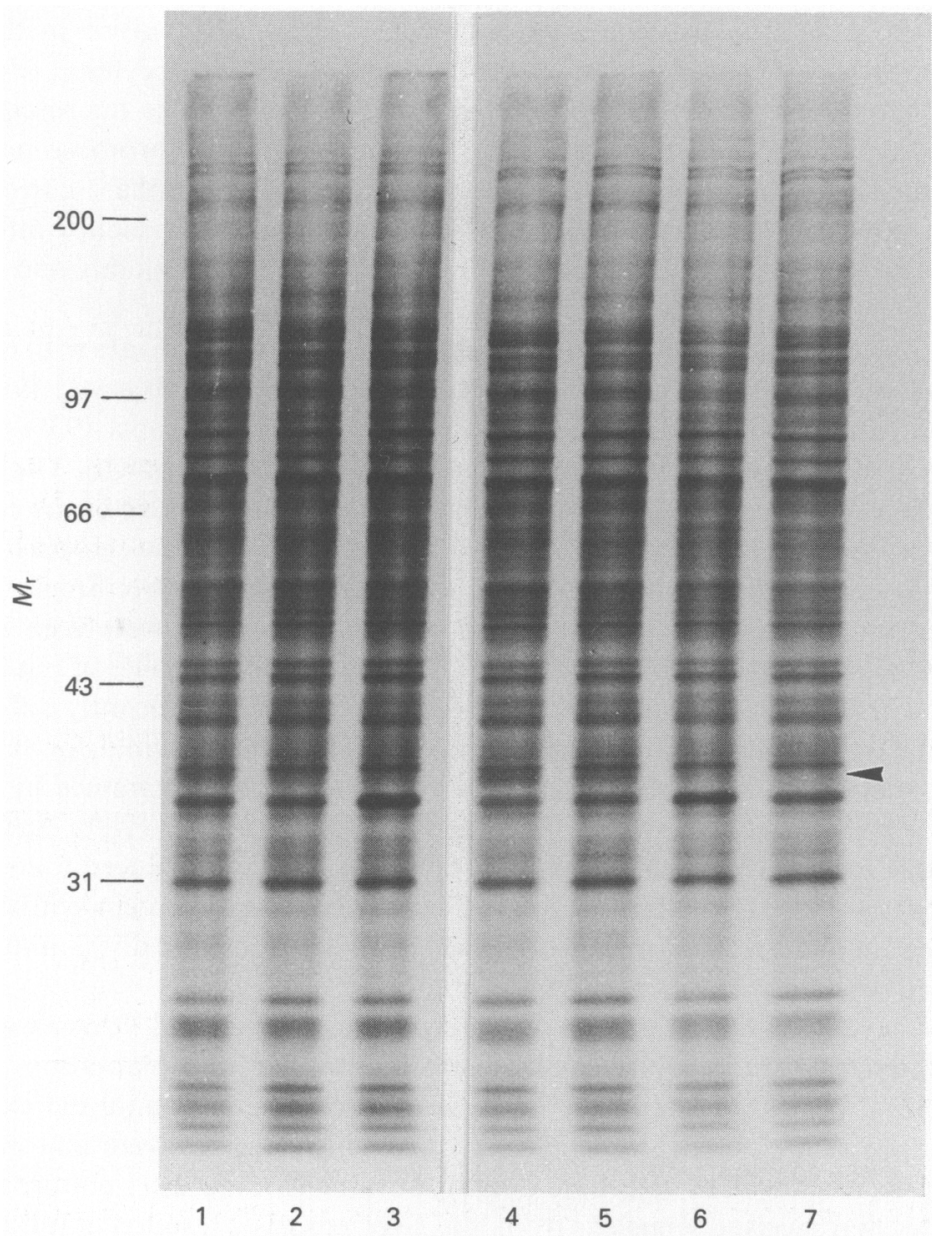

Fig. 3. One-dimensional sodium dodecyl sulphate, polyacrylamide gel electrophoresis separation of $\left[{ }^{35} \mathrm{~S}\right]$-methionine polypeptides synthesized during $2 \mathrm{~h}$ of labelling in control oocytes and enucleated oocytes. Control oocytes were labelled at $10(1), 14(2)$ or 16 (3) h after human chorionic gonadotrophin (hCG). Oocytes enucleated at $10 \mathrm{~h}$ after hCG were labelled after culturing for $0(4), 2(5), 4(6)$, and $6 \mathrm{~h}$ (7). Arrow head indicates position of polypeptide, lower band of $M_{\mathrm{r}} 37 \times 10^{3}$, whose synthesis is detectable in tracks (1), (2), (4) and (5) but not in tracks (3) and (7). The band $35 \times 10^{3}$ polypeptide that is a maternally encoded polypeptide (Howlett \& Bolton, 1985) is clear.

through synthesis of the lower band of the $37 \times 10^{3} M_{\mathrm{r}}$ complex (Fig. 3, arrow head) was reduced with time after ovulation (lanes 2,3 ) or enucleation (lanes 6,7 ).

\section{Discussion}

Offspring have been produced from nuclei of 8- to 16-cell sheep embryos fused with enucleated oocytes (Willadsen, 1986) and this method has been repeated in cattle (Prather et al., 1987), rabbits (Stice \& Robl, 1988) and sheep (Smith \& Wilmut, 1989). In these studies, the enucleation of the oocyte was carried out at metphase II. This method is not very reliable as it is often difficult, even by differential interference microscopy, to locate the position of the metaphase II chromosomes within the oocyte. 
In the present study, to overcome the technical difficulties involved in the enucleation of secondary oocytes, we attempted to remove the chromosomes from oocytes at telophase of the first meiotic division by micromanipulation using differential interference microscopy. At this time, extrusion of the first polar body is not completed and the separated chromosomes at each pole are connected to each other by the meiotic spindle apparatus. The telophase chromosomes, spindle apparatus and extruding region of cytoplasm were, therefore, easily sucked into the enucleation pipette. The advantage of this method is that chromosomes can be reliably and quickly removed, with a small amount of cytoplasm, without any staining.

It has been reported that newly ovulated oocytes are difficult to activate with ethanol treatment, but that the activation rate increases following in vitro culture (Webb et al., 1986). Although the oocytes at $10 \mathrm{~h}$ after hCG injection are also difficult to activate, most $(93 \%)$ nonmanipulated oocytes can be activated after culturing for $4-6 \mathrm{~h}$ in vitro (data not shown). The activation rate of the reconstituted oocytes could also be significantly increased by culture of the enucleated oocytes before nuclear transplantation (data not shown). Thus the ability of the cytoplast to mature and be activated is independent of the chromosomes, both in vivo and in vitro. Similar changes of cytoskeletal organization, activation rate and type of parthenogenesis were seen in mouse oocytes matured in vivo and in vitro (Webb et al., 1986). The polypeptide profile of enucleated oocytes at anaphase of the first meiotic division and matured in vitro is not significantly different from that of oocytes matured in vivo. It is known that the protein synthesis required for the transition from metaphase I to metaphase II (Hashimoto \& Kishimoto, 1988) is programmed by messenger RNAs in the oocyte cytoplasm (Globs \& Stein, 1976; Crozet \& Szollosi, 1980). Schultz et al. (1978) reported that nucleate and anucleate fragments of mouse oocytes produced following treatment of fully grown oocytes with cytochalasin B showed similar profiles of protein synthesis. These studies indicate that the complete transition from telophase of the first meiotic division to metaphase II can be accomplished without the presence of chromosomes.

The rate of development of the reconstituted oocytes in vitro and in vivo was investigated, to assess the suitability of the cytoplast as recipient for nuclear transplantation. The oocytes that received a nucleus from a 2-cell embryo or ICM cell underwent ethanol-induced activation at a frequency equal to that observed in other studies in which oocytes were matured in vivo. Of the oocytes which received an ICM cell, 10\% developed to blastocysts after culture for 4 days. Moreover, the oocytes that received a nucleus from late 2-cell embryos resulted in full-term development after transfer to recipients. This result clearly shows that the enucleated cytoplasm can be used as a recipient for nuclear transplantation.

In this study, most of the reconstituted oocytes emitted a polar body after activation treatment, in which the polar body certainly contained chromosomes derived from the donor nucleus. The polar body may be emitted as a result of mitosis of the donor nucleus. Czolowska et al. (1984) reported that interphase nuclei, in one case, fused with mouse oocytes underwent mitosis arranged on an extra spindle and emitted a polar body. Whether the reconstituted embryos with one polar body and pronucleus had a diploid set of chromosomes is unclear. However, at least some of them would have a normal diploid set of chromosomes after emission of the polar body, since live young have been produced from such embryos in the present study.

Enucleated mouse zygotes that reconstituted with a nucleus from 4- or 8-cell embryos or ICM cells were unable to develop in vitro (McGrath \& Solter, 1984; Howlett et al., 1987; Tsunoda et al., 1987). Robl et al. (1986) reported that enucleated 2-cell embryos which received a nucleus from 4and 8-cell embryos developed to blastocysts. This was confirmed by Tsunoda et al. (1987) and live young were produced from such reconstituted 2-cell embryos. Kono et al. (1991) reported that transplantation of a single nucleus from 2- or 4-cell embryos into one of the enucleated blastomeres of 2-cell embryo resulted in successful production of identical twin and triplet mice. However, the nuclei transplanted into enucleated 2-cell embryos were not fully transformed to normal 2-cell nuclei. In such embryos, therefore, the compaction occurred at the 4-cell stage (Tsunoda et al., 1987) and the resulting blastocysts had significantly fewer cells (Robl et al., 1986). Kono \& 
Tsunoda (1989) also reported that hatched blastocysts that were derived from single blastomeres from 8-cell mouse embryos fused into enucleated halves of 2-cell embryos lacked ICM completely. When ICM cells were transferred, the reconstituted 2-cell embryos did not develop at all (Tsunoda et al., 1987).

The capacity for nuclear development after transfer to an enucleated oocyte differs among species. Transplantation of a nucleus from an 8-16-cell embryo to an enucleated oocyte resulted in production of offspring after transfer to a recipient in cattle (Prather et al., 1987), in sheep (Willadsen, 1986; Smith \& Wilmut, 1989) and in rabbits (Stice \& Robl, 1988), but not in mice. In the present study, we succeeded in producing live young from enucleated oocytes that received nuclei from late 2-cell embryos. The stage of the donor embryo that is consistent with development of the reconstituted oocytes to term may coincide with the stage at which transcription of the embryonic genome begins; i.e. the middle of the 2-cell stage in mice (Johnson, 1981; Flach et al., 1982) and the 8-16-cell stage in sheep, cattle and rabbits (Cotton et al., 1980; Camous et al., 1986; Crosby, 1988). Recently, however, Smith \& Wilmut (1989) reported that ICM cells transferred to enucleated oocytes in sheep allowed development to term. In mice, it has been shown that nuclei from ICM (Tsunoda et al., 1988; and the present results), primordial germ cells (Tsunoda et al., 1989), and teratocarcinoma cells (Modlinski et al., 1990) can undergo limited reprogramming after transplantation into enucleated oocytes.

We thank G.T. O'Nell, AFRC, Institute of Animal Physiology and Genetic Research, Edinburgh Research Station, for critical evaluation of the manuscript. This work was supported in part by the Hayashida Fund for Biotechnological Study of Tokyo University of Agriculture. We thank Y. Sotomaru for expert technical assistance.

\section{References}

Briggs, R. \& King, T.J. (1952) Transplantation of living nuclei from blastula cells into enucleated frog's eggs. Proc. Natl Acad. Sci. USA 38, 455-463.

Briggs, R. (1979) Genetics of cell type determination. In Int. Rev. Cytol. Suppl. 9, Nuclear Transplantation, pp. 107-127. Eds J. F. Danielli \& M. A. Diberardino. Academic Press, New York.

Bonner, W.M. \& Laskey, R.A. (1974) A film detection method for tritium-labelled proteins and nucleic acid in polyacrylamide gels. Eur. J. Biochem. 46, 83-88.

Cotton, R.W., Manes, C. \& Hamkalo, B.A. (1980) Electron microscopic analysis of RNA transcription in preimplantation rabbit embryos. Chromosoma 79, 169-178.

Camous, S., Kopency, V. \& Flechon, J.E. (1986) Autoradiographic detection of the earliest stage of $\left[{ }^{3} \mathrm{H}\right]$ uridine incorporation into the cow embryo. Biol. Cell 58, 195-200.

Crosby, I.M., Gandolfi, F. \& Moor, R.M. (1988) Control of protein synthesis during early cleavage of sheep embryos. J. Reprod. Fert. 82, 769-775.

Crozet, N. \& Szollosi, D. (1980) Effects of actinomycin D and $\alpha$-amanitin on the nuclear ultrastructure of mouse oocytes. Biol. Cell. 38, 163-170.

Czolowska, R., Modlinski, J.A. \& Tarkowski, A.K. (1984) Behaviour of thymocyte nuclei in non-activated and activated mouse oocytes. J. Cell Sci. 69, 19-34.

Cuthbertson, K.S.R. (1983) Parthenogenetic activation of mouse oocytes in vitro with ethanol and benzylalcohol. J. exp. Zool. 226, 311-314.
DiBerardino, M.A. (1980) Genetic stability and modulation of metazoan nuclei transplanted into eggs and oocytes. Differentiation 17, 17-30.

Ebert, K.M., Hammer, R.E. \& Papaiannou, V.E. (1985) A simple method for counting nuclei in the preimplantation mouse embryo. Experimentia 41, 1207-1209.

Eibs, H.G. \& Spielman, H. (1977) Differential sensitivity of preimplantation mouse embryos to UV irradiation in vitro and evidence for post replication repair. Radiat. Res. 71, 367-376.

Flach, G., Johnson, M.H., Braude, P.R., Taylor, R.A.S. \& Bolton, V.N. (1982) The transition from maternal and embryonic control in the 2-cell mouse embryo. EMBO J. 1, 681-686.

Globs, M.S. \& Stein, M.P. (1976) Qualitative patterns of protein synthesis in the mouse oocyte. J. exp. Zool. 198, 337-342.

Gurdon, J.B. \& Uehlinger, V. (1966) 'Fertile' intestine nuclei. Nature, Lond. 210, 1240-1241.

Hashimoto, N. \& Kishimoto, T. (1988) Regulation of meiotic metaphase by a cytoplasmic maturationpromoting factor during mouse oocyte maturation. Devl Biol. 126, 242-252.

Howlett, S.K. \& Bolton, V.N. (1985) Sequence and regulation of morphological and molecular events during the first cell cycle of mouse embryogenesis. $J$. Embryol. exp. Morph. 87, 175-205.

Howlett, S.K., Barton, S.C. \& Surani, M.A. (1987) Nuclear cytoplasm interactions following nuclear Downloaded from Bioscientifica.com at 04/26/2023 09:39:07AM via free access 
transplantation in mouse embryos. Development 101, 915-923.

Johnson, M.H. (1981) The molecular and cellular basis of preimplantation mouse development. Biol. Rev. 56, $463-498$.

Kono, T. \& Tsunoda, Y. (1988) Nuclear transplantation of rat embryos. J. exp. Zool. 248, 303-305.

Kono, T. \& Tsunoda, Y. (1989) Development of single blastomeres from four- and eight-cell mouse embryos fused into the enucleated half of a two-cell embryo. Gamete Res. 22, 427-434.

Kono, T., Tsunoda, Y. \& Nakahara, T. (1991) Production of identical twin and triplet mice by nuclear transplantation. J. exp. Zool. 257, 214-219.

Laemmli, U.K. (1970) Cleavage of structure proteins during the assembly of the head of bacteriophage T4. Nature, Lond. 227, 680-685.

McGrath, J. \& Solter, D. (1983) Nuclear transplantation in the mouse embryo by microsurgery and cell fusion. Science, N.Y. 220, 1300-1303.

McGrath, J. \& Solter, D. (1984) Inability of mouse blastomere nuclei transferred to enucleated zygotes to support development in vitro. Science, N.Y. 226, $1317-1319$.

Modlinski, J.A., Gerhauser, D., Lioi, B., Winking, H. \& Illmensee, K. (1990) Nuclear transfer from teratocarcinoma cells into mouse oocytes and eggs. Development 108, 337-348.

Prather, R.S., Barnes, F.L., Sims, M.M., Robl, J.M., Eyestone, W.H. \& First, N.L. (1987) Nuclear transplantation in bovine embryo: assessment of donor nuclei and recipient oocyte. Biol. Reprod. 37, $859-866$.

Quinn, P., Barros, C. \& Whittingham, D.G. (1982) Preservation of hamster oocytes to assay the fertilizing capacity of human spermatozoa. J. Reprod. Fert. 66, $161-168$.

Robl, J.M., Gilligan, B., Critser, E.S. \& First, N.L. (1986) Nuclear transplantation in moue embryos: assessment of recipient cell stage. Biol. Reprod. 34, 733-739.
Schultz, R.M., Letourneau, G.E. \& Wassarman, P.A. (1978) Meiotic maturation of mouse oocytes in vitro: protein synthesis in nucleate and anucleate oocyte fragments. J. Cell Sci. 30, 251-264.

Smith, L.C. \& Wilmut, I. (1989) Influence of nuclear and cytoplasmic activity on the development in vivo of sheep embryos after nuclear transplantation. Biol. Reprod. 40, 1027-1035.

Stice, S.L. \& Robl, J.M. (1988) Nuclear reprogramming in nuclear transplanted rabbit embryos. Biol. Reprod. 39, 657-664.

Tsunoda, Y., Yasui, T., Nakamura, K., Uchida, T. \& Sugie, T. (1986) Effect of cutting the zona pellucida on pronuclear transplantation in the mouse. $J$. exp. Zool. 240, 119-125.

Tsunoda, Y., Yasui, T., Shioda, Y., Nakamura, K., Uchida, T. \& Sugie, T. (1987) Full term development of mouse blastomere nuclei transplanted to enucleated two-cell embryos. J. exp. Zool. 242, 147-151.

Tsunoda, Y., Shioda, Y., Onodera, M., Nakamura, K., Uchida, T. \& Sugie, T. (1988) Differential sensitivity of mouse pronuclei and zygote cytoplasm to Hoechst staining and ultraviolet irradiation. J. Reprod. Fert. 82, $173-178$.

Tsunoda, Y., Tokunaga, T., Imai, H. \& Uchida, T. (1989) Nuclear transplantation of male primordial germ cells in the mouse. Development 107, 407-411.

Webb, M., Howlett, S.K. \& Maro, B. (1986) Parthenogenesis and cytoskeletal organization in ageing mouse eggs. J. Embryol. exp. Morph. 95, 131-145.

Whittingham, D.G. (1971) Culture of mouse ova. $J$. Reprod. Fert., Suppl. 14, 7-21.

Willadsen, S.M. (1986) Nuclear transplantation in sheep embryos. Nature, Lond. 302, 63-65. 